\title{
PERFORMANCE STUDY OF LiBOB/LiTFSI ELECTROLYTE SALT IN THE ALL-SOLID-STATE LITHIUM-ION BATTERY
}

\author{
Christin Ratri, Qolby Sabrina and Titik Lestariningsih \\ Research Centre for Physics, Indonesian Institute of Sciences \\ Kawasan Puspiptek Gd. 442, Tangerang Selatan - Banten 15314 \\ E-mail: chri014@lipi.go.id
}

Received: 24 December 2019

Revised: 19 April 2020

Accepted: 26 April 2020

\begin{abstract}
PERFORMANCE STUDY OF LiBOB/LiTFSI ELECTROLYTE SALT IN THE ALL-SOLIDSTATE LITHIUM-ION BATTERY. Solid polymer electrolyte is developed mainly to provide safer lithiumion battery upon high temperature operation. In this research, we employ LiBOB and LiTFSI electrolyte salt in various concentration to replace commercially used $\mathrm{LiPF}_{6}$ salt. Solution cast method was performed to produce polymer electrolyte membrane. PVdF-HFP was chosen as polymer matrix due to high dielectric constant, and compatibility to wide array of electrode materials as well as electrolyte salts. Higher amount of electrolyte salts contributes to thicker membrane and hence higher current output of the lithium-ion battery half-cells. SEM, FT-IR spectroscopy, and cyclic voltammetry measurement was conducted to evaluate li-ion battery cell performance. Between the two electrolyte salts used in this experiment, LiTFSI salt exhibited better performance compared to LiBOB.
\end{abstract}

Keywords: LiTFSI, LiBOB, Li-ion battery, PVdF, Polymer electrolyte

\begin{abstract}
ABSTRAK
STUDI PERFORMA GARAM ELEKTROLIT LiBOB/LITFSI DALAM BATERAI ION LITIUM PADAT. Elektrolit polimer padat dikembangkan untuk menyediakan baterai lithium-ion yang lebih aman pada operasi suhu tinggi. Dalam penelitian ini, kami menggunakan garam elektrolit litium bis(oxalato) borat (LiBOB) dan litium bis(trifluoromethanesulfonyl)imide (LiTFSI) dalam berbagai konsentrasi untuk menggantikan garam litium heksafluoropospat $\left(\mathrm{LiPF}_{6}\right)$ yang digunakan secara komersial. Metode solution cast digunakan untuk membuat membran elektrolit polimer. Poly(vinylidene fluoride-cohexafluorophosphate) PVdF-HFP dipilih sebagai matriks karena konstanta dielektrik yang tinggi, dan kompatibilitas dengan beragam bahan elektroda serta garam elektrolit. Jumlah garam elektrolit yang lebih tinggi berkontribusi pada membran yang lebih tebal dan keluaran arus sel-baterai lithium-ion yang lebih tinggi. Scanning Electron Microscope (SEM), spektroskopi Fourier-Transform Infra-Red (FT-IR), dan pengukuran voltametri siklik dilakukan untuk mengevaluasi performa sel baterai. Di antara dua garam elektrolit yang digunakan dalam percobaan ini, garam LiTFSI menunjukkan kinerja yang lebih baik dibandingkan LiBOB.
\end{abstract}

Kata kunci: LiTFSI, LiBOB, Baterai ion litium, PVdF, Elektrolit polimer

\section{INTRODUCTION}

As the technology grows more and more sophisticated, the urge for portable devices demands reliable energy storage. Secondary battery was first introduced commercially circa 1990, with NiMH and NiCd electrodes [1]. This soon met its limitation when the capacity fades relatively quickly due to the memory effect. Then comes lithium-ion battery with better stability as well as capacity, first introduced by Sony Corporation around year 1990 [2]. 
Lithium-ion battery consists of four main components: anode, cathode, separator, and electrolyte. Separator stands between electrodes to prevent short-circuit, but they should still be able to transport lithium-ion from positive to negative electrode and vice versa during charging. Commercially available secondary battery used liquid electrolyte made of lithium hexafluorophosphate $\left(\mathrm{LiPF}_{6}\right)$ electrolyte salt dissolved in mixture of ethylene carbonate (EC)/ethyl methyl carbonate (EMC) organic solvent. This electrolyte salt is known to be easily degraded into $\mathrm{PF}_{6}^{-}$and exposure of this compound to the solvent would produce toxic HF gases $[3,4]$. Furthermore, combined with the liquid organic solvent(s), it has detrimental effect on the electrode which decrease the stability of the battery cell especially in high temperature operation $[5,6]$.

Solid polymer electrolyte (SPE) was developed by Wright, et al. on mid 1970s by incorporating natrium and kalium ions into polyethylene oxide (PEO) $[7,8]$. The SPE membrane acts as both separator and electrolyte, therefore capable to isolate electrons yet porous enough for lithium ion movement between electrodes. The disadvantage of the SPE is very low conductivity compared to conventional liquid electrolyte [9].

In this paper, solid polymer electrolyte was assembled using lithium bis(oxalato) borate (LiBOB) and lithium bis(trifluoromethanesulfonyl) imide (LiTFSI) electrolyte salt. Currently, commercial Li-ion battery used $\mathrm{LiPF}_{6}$ as electrolyte salt owing to its relatively higher current output. It is however unstable under elevated temperature, and exposure of the salt to organic solvent lead was found to cause electrode material degradation especially along the solid-electrolyte interface [10].

It was known from these studies that $\mathrm{LiBOB}$ and LiTFSI are superior compared to $\mathrm{LiPF}_{6}$ in terms of stability during charging and discharging [5,10-13]. Incorporating LiBOB and LiTFSI as gel polymer electrolyte (GPE) form by means of electrospinning and solution cast method has seen promising results $[14,15]$. GPE membranes were activated by immersing it in liquid electrolyte solution. It is however, still imposing safety hazard because aqueous solvent was still involved and incompatibility with active materials could lead to electrode degradation [16]. Moreover, mechanical integrity of gel polymer electrolyte is less favorable to be applied in all-solid-state lithium-ion battery which requires more flexibility [14]. This research aims to eliminate the involvement of organic solvent altogether in order to improve safety and prevent electrode degradation.

Poly(vinylidene fluoride-co-hexafluoro-propylene) (PVdF-HFP) was chosen as polymer matrix owing to its high dielectric constant and stable mechanical integrity. Its semicrystalline properties help with ionic conductivity, and are potentially preferable for operation at elevated temperature [17]. It was also found that LiTFSi is poorly soluble in PEO matrix, hence the choice of PVdF-HFP as polymer matrix [18].

\section{EXPERIMENTAL METHOD}

\section{Materials and Instruments}

Polymer electrolytes were synthesized using solution cast method. LiBOB and LiTFSI electrolyte salts were obtained from Sigma Aldrich and heated overnight to remove moisture. Polymer PVdF-HFP from Mercks was used without further treatment.

These SPE membranes were characterized using Fourier Transform Infrared (FT-IR) spectroscopy, and Field Emission Scanning Electron Microscope (FE-SEM). FT-IR Thermoscientific iS-10 was used to observe functional groups interaction in the system. We used attenuated total reflection (ATR) mode where ambient air was taken as background spectra. Measurement was taken within wavelength of 4000 to $400 \mathrm{~cm}^{-1}$ at room temperature. Morphology of membrane surface and cross section was observed using FE-SEM Jeol JIB-4610F with $5 \mathrm{kV}$ acceleration voltage.

\section{Method and Procedure}

PVdF-HFP were dissolved in N,N-dimethylacetamide (DMAC) solvent on a hot plate at $50^{\circ} \mathrm{C}$ until clear, homogenous slurry was formed. Electrolyte salts were then added and the slurry was mixed again for 2 hours. The final slurry was then poured onto a petri dish and dried in atmospheric condition. The resulting product is a white, free-standing membrane. Solution containing different amount of electrolyte salts were synthesized and denoted with ratio according to the Table 1.

Table 1. Various Concentration of Electrolyte Salt in SPE sample

\begin{tabular}{ccc}
\hline Sample notation & PVdF-HFP $(\mathrm{g})$ & LiBOB or LiTFSI $(\mathrm{g})$ \\
\hline LiBOB $20 \% /$ & 1 & 0.25 \\
LiTFSI $20 \%$ & & \\
LiBOB $40 \% /$ & 1 & 0.67 \\
LiTFSI $40 \%$ & & \\
LiBOB $60 \% /$ & 1 & 1.5 \\
LiTFSI $60 \%$ & & \\
\hline
\end{tabular}

Solid polymer electrolyte membrane was then cut in circular shape and assembled in the form of CR2032 half-cell with commercial double-sided lithium iron phosphate $\left(\mathrm{LiFePO}_{4}\right)$ electrode sheet (MTI Corporation) and metal lithium (MTI Corporation) as electrodes. The assembling process took place in a glove box conditioned with argon gas where moisture exposure kept at $<100 \mathrm{ppm}$. The sample cells were then tested in WBCS3000 Battery Cycler at room temperature to observe their performance during charging and discharging. Performance of the SPE membrane was evaluated by the current output parameter. 


\section{RESULT AND DISCUSSION}

\section{FT-IR spectroscopy}

Results of FT-IR spectroscopy of solid polymer electrolyte membrane containing LiBOB and LiTFSI salt are shown on Figure 1 and Figure 2, respectively. LiBOB compound was represented by vibration peaks at wavenumber $723,882,1633$, and $1810 \mathrm{~cm}^{-1}$ showing $\mathrm{C}-\mathrm{O}-$ $\mathrm{O}$ bending vibration, $\mathrm{O}-\mathrm{B}-\mathrm{O}$ asymmetric stretch, $\mathrm{C}-\mathrm{O}-\mathrm{O}$ asymmetric stretch, and $\mathrm{C}=\mathrm{O}$ oscillation, respectively [12].

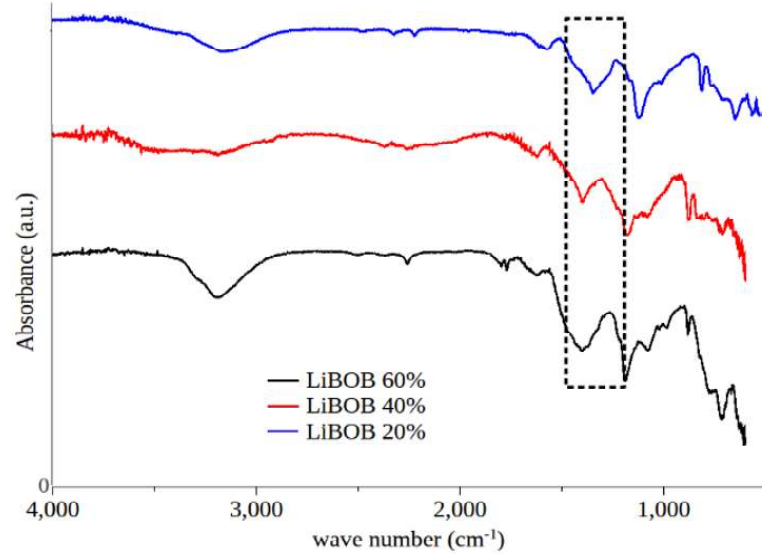

Figure 1. FT-IR spectra of solid polymer electrolyte membrane containing LiBOB salt.

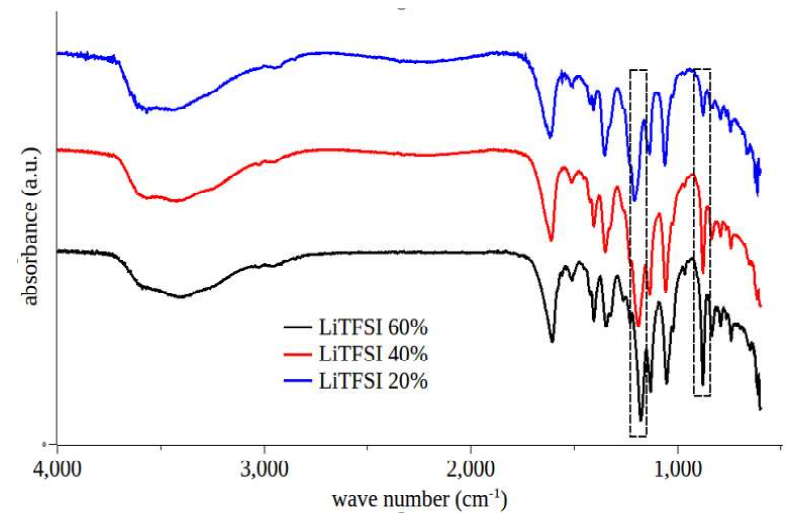

Figure 2. FT-IR spectra of solid polymer electrolyte membrane containing LiTFSI salt.

$\mathrm{C}-\mathrm{O}-\mathrm{O}$ asymmetric stretch at wave number $1633 \mathrm{~cm}^{-1}$ was seen to be sharper with increasing LiBOB concentration, which is justified since higher concentration means more amount of bond existing in the measurement sample [19]. For solid polymer electrolyte containing LiTFSI salt, fingerprint region was identified by vibration peaks at $1384,974,795$, and $760 \mathrm{~cm}^{-1}$, which correspond to alpha-phase crystal. $\mathrm{CF}_{2}$ symmetrical stretching at 1064 and $1148 \mathrm{~cm}^{-1}$ represented PVdF-HFP where displacement of these peaks indicated strong interaction with LiTFSI salt. Pure PVdF-HFP matrix is also identified by $\mathrm{C}-\mathrm{C}$ symmetric stretching at
$872 \mathrm{~cm}^{-1}$ as well as C-F and CF3 stretching at 975 and $796 \mathrm{~cm}^{-1}$, respectively [20]. Peak intensity along the region of 1420 to $1380 \mathrm{~cm}^{-1}$ has also changed, which corresponds to $\mathrm{CH}_{2}$ group vibrations $[21,22]$.

\section{SEM}

Surface and cross section morphology of solid polymer electrolyte membrane are displayed in Figure 3 and Figure 4 for LiBOB and LiTFSI, respectively. Polymer membrane before addition of electrolyte salt, noted by $\mathrm{LiBOB} 0 \%$, can be seen on Figure 3(a).
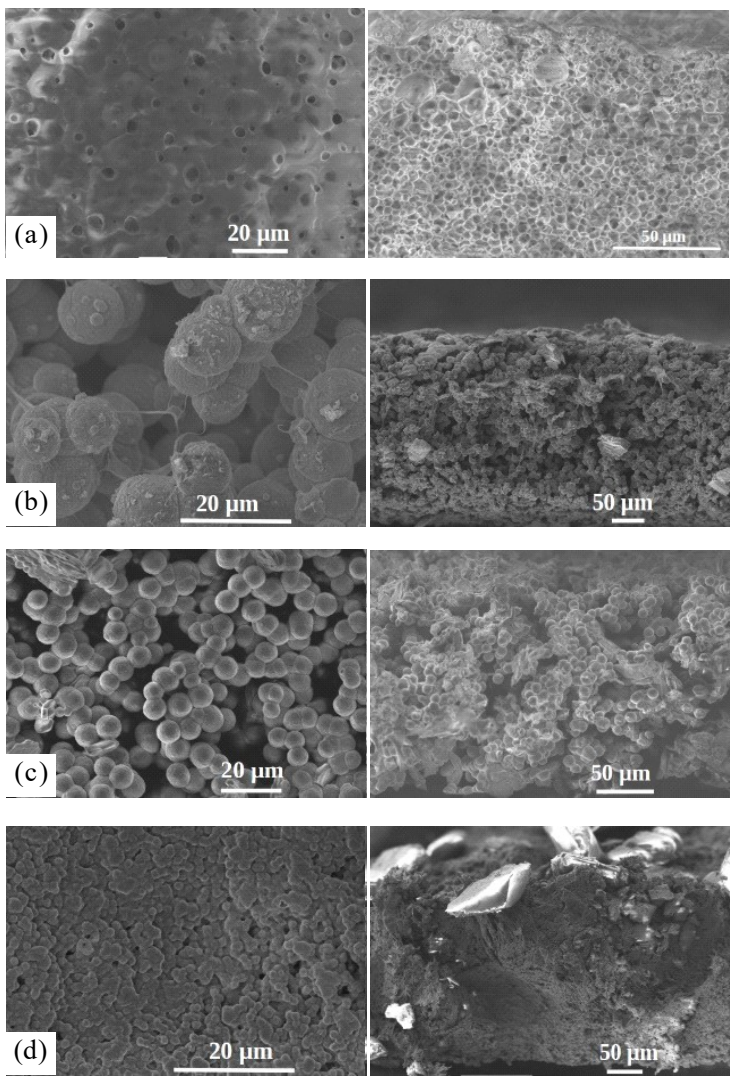

Figure 3. Surface (left column) and cross section (right column) morphology of solid polymer electrolyte containing LiBOB (a) $0 \%$, (b) $20 \%$, (c) $40 \%$, and (d) $60 \%$.

Polymer-only membrane (Figure 3(a)) displayed relatively smooth surface with visible pores, proving that PVdF-HFP can be a good conductive separator. Pores enable better ionic transport between electrodes while maintaining isolative purpose to avoid short-circuit [23]. Membrane thickness of SPE without electrolyte salt has been measured at $88 \mu \mathrm{m}$ (ImageJ). Thickness of solid polymer electrolyte membrane containing LiBOB was also measured, and resulted in 167, 315, and $363 \mu \mathrm{m}$ for $\mathrm{LiBOB}$ $20 \%, 40 \%$, and $60 \%$, respectively.

More content of electrolyte salt in the slurry resulted in thicker membrane. Pores are less pronounced with more salt content. Excessive amount of pores hinders ionic movement between electrodes because 

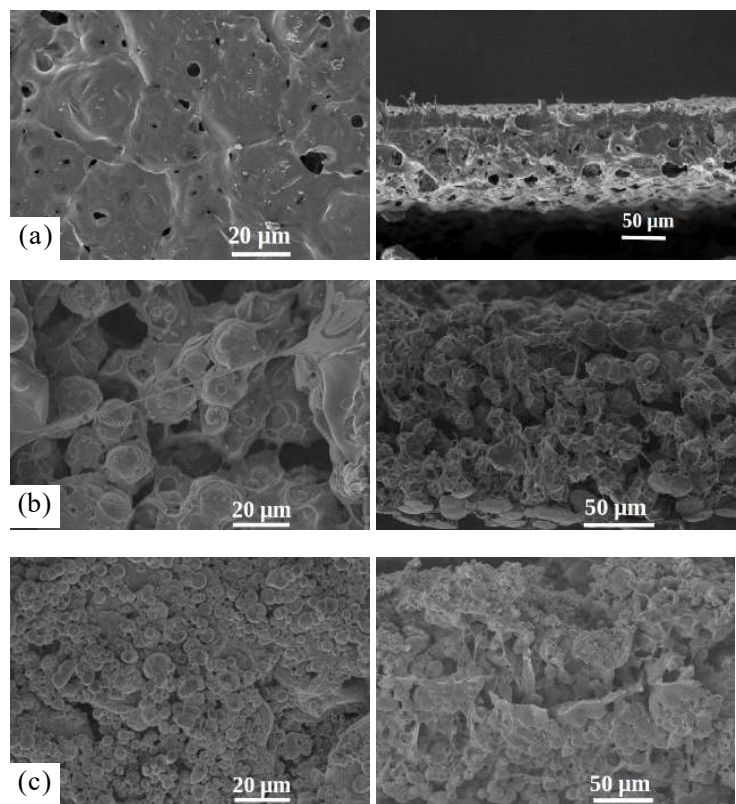

Figure 4. Surface (left column) and cross section (right column) morphology of solid polymer electrolyte containing LiTFSI (a) $20 \%$, (b) $40 \%$, and (c) $60 \%$.

pores are essentially voids [24]. CV test results also confirmed this, where solid polymer electrolyte containing highest amount of both LiBOB and LiTFSI salt showed best performance. It should be noted, however, that there are certain points where higher salt concentration could lead to disadvantageous result, as reported by Aziz [25] and Camacho-Forero [26].

Similar behavior was shown on the cross-section morphology, where LiBOB 60\% (Figure 4(d)) appear to have the most dense layer. This in turn has an impact to the performance, as explained in the CV/CD section.

Membrane thickness was also measured with ImageJ. These membranes have thickness of 88,143 , and $197 \mu \mathrm{m}$ for LiTFSI $20 \%$, LiTFSI $40 \%$, and LiTFSI $60 \%$, respectively.

\section{Cyclic Voltammetry (CV)}

Cyclic voltammetry profile of $\mathrm{Li}-\mathrm{LiFePO}_{4}$ halfcells containing solid polymer electrolyte were recorded at a rate of $0.1 \mathrm{C}$ between 2.5 and $4.2 \mathrm{~V}$ at room temperature. The cyclic measurement of conventional battery cell containing liquid electrolyte was displayed on Figure 5. This cell presented discharge current of $9 \mathrm{~mA}$ at first cycle and dropped to $4.7 \mathrm{~mA}$ at third cycle.

Cyclic voltammetry profiles of battery cell with LiBOB and LiTFSI membrane of different concentration are shown on Figure 6 and 7. For all sample, the discharge current has decreased from first to third cycle. As an example, sample LiBOB 60\% (Figure 6(c)) showed that the current dropped from $0.9 \mu \mathrm{A}$ at first cycle to $0.6 \mu \mathrm{A}$ at third cycle.

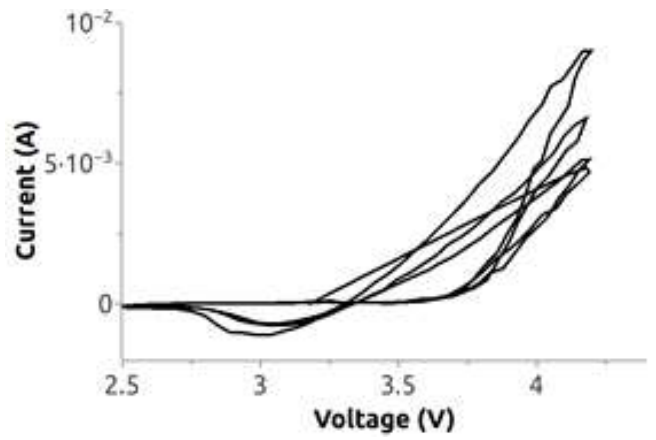

Figure 5. Cyclic voltammetry profile of battery cell with liquid electrolyte.

Looking at various concentration of $\mathrm{LiBOB}$ and LiTFSI salt, it was seen that higher amount of electrolyte salt resulted in higher discharge current. This may be due to thicker layer of membrane containing electrolyte salt in polymer matrix. It also indicates well-dispersed electrolyte across the surface and cross section, where thicker membrane helps with transporting lithium ion between electrodes. Similar with the case for sample with
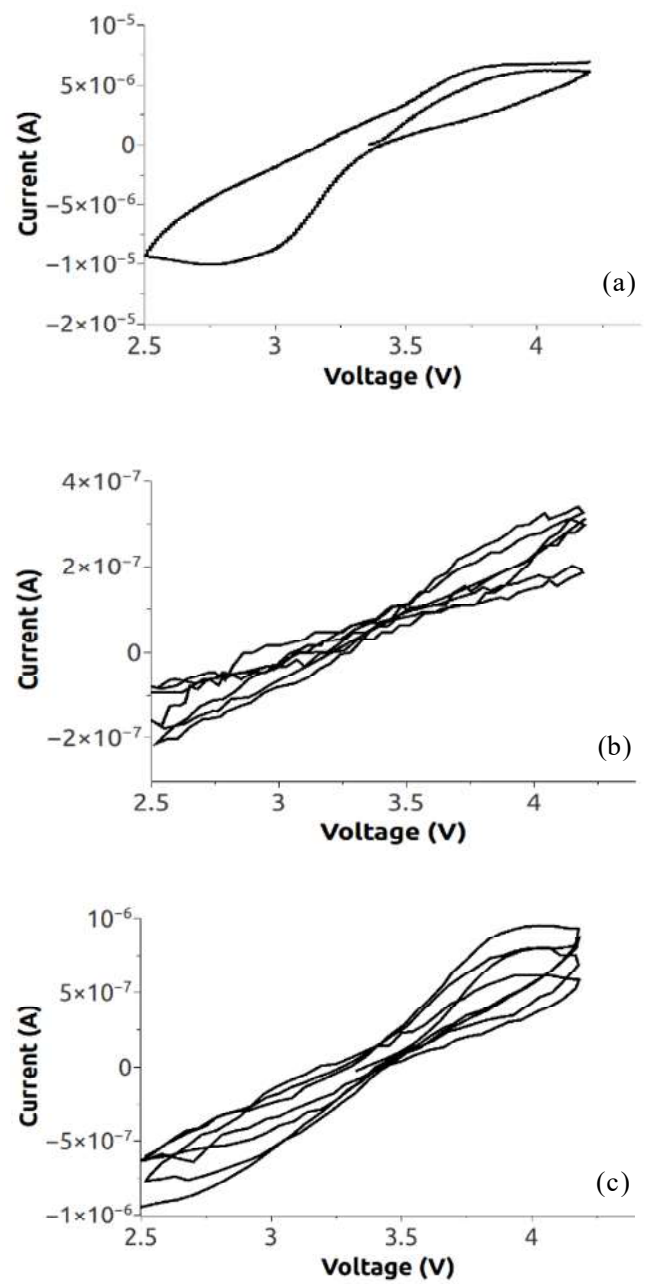

Figure 6. Cyclic voltammetry profile of battery cell with (a) $20 \%$, (b) $40 \%$, (c) $60 \% \mathrm{LiBOB}$ 

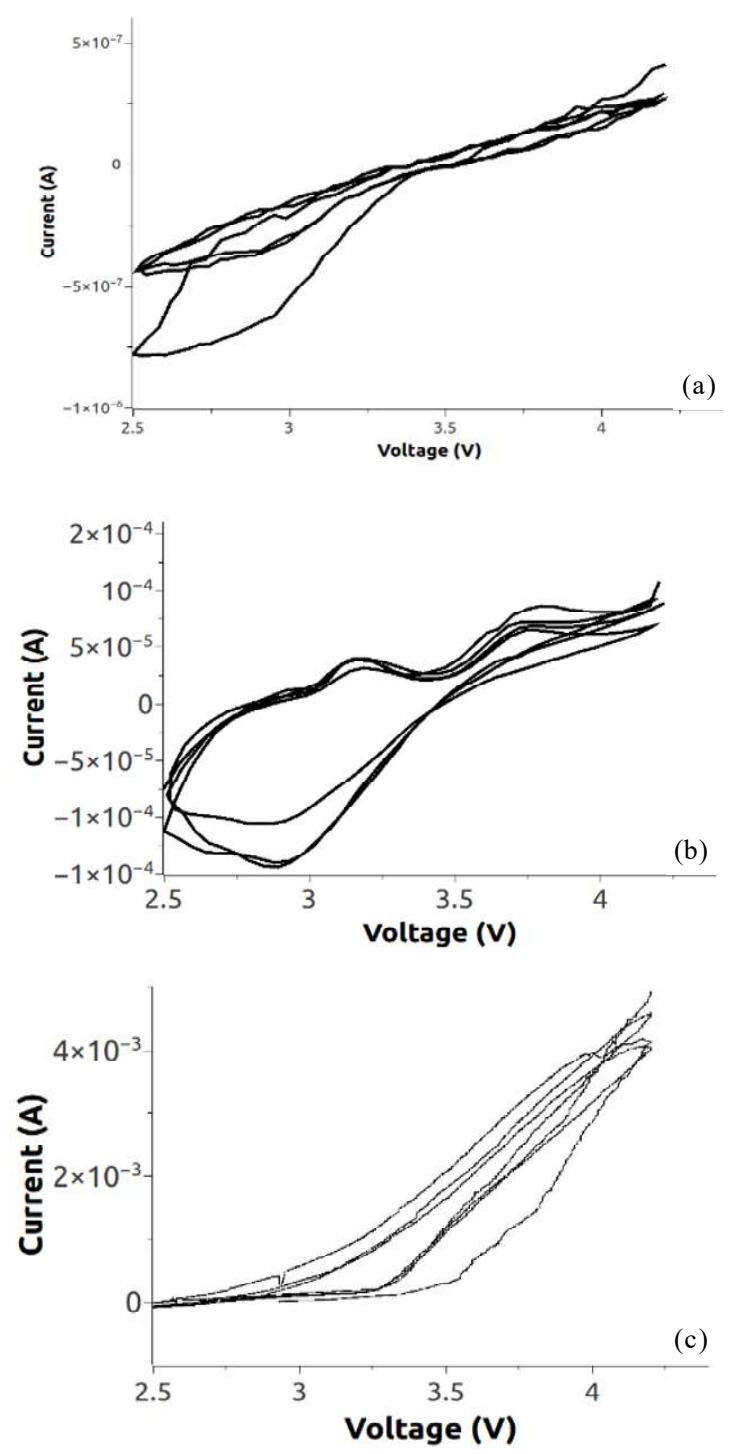

Figure 7. Cyclic voltammetry profile of battery cell with (a) $20 \%$, (b) $40 \%$, (c) $60 \%$ LiTFSI

LiTFSI, cell current dropped from $4.5 \mathrm{~mA}$ to $4 \mathrm{~mA}$ from first to third cycle.

Results of current output parameter measurement is displayed on Table 2. In general, overall performance of half-cell battery with LiTFSI is better compared to LiBOB in terms of discharge current, e.g 0.3ì for LiBOB vs $0.075 \mathrm{~mA}$ for diffuse LiTFSI as seen on Figure 6(b) and 7(b), respectively.

Voltammograms shown on Figure 5, 6, and 7 did not display typical reversible behavior of a secondary battery cell usually characterized by distinctive forward and reverse scan peak. This could be attributed to relatively slow scan rate - we used $5 \mathrm{mVs}^{-1}$ scan rate in this experiment. It is possible to miss the reduction and oxidation peak at this rate since slow rate will build up thicker diffusion layer but since both the separator and electrodes in this experiment contains lithium ion the reduction and oxidation products cannot be measured properly[27]. This could also indicate capacitive beha-
Table 2. Summary of 1 st Cycle Current Output.

\begin{tabular}{cc}
\hline Sample & $\begin{array}{c}\text { 1st cycle current } \\
\text { output }(\mu \mathrm{A})\end{array}$ \\
\hline $\begin{array}{c}\text { Liquid } \\
\text { electrolyte }\end{array}$ & 9000 \\
LiBOB 20\% & 5 \\
LiBOB 40\% & 0.32 \\
LiBOB 60\% & 0.9 \\
LiTFSI 20\% & 0.28 \\
LiTFSI 40\% & 75 \\
LiTFSI 60\% & 4500 \\
\hline
\end{tabular}

vior of the electrolyte membrane, in which non-Faradaic process are identified. Electron contributions are far less dominant compared to ions as charge carriers, which promotes electrical double layer at the electrolyteelectrode interface [28]. This could definitely help interfacial contact, and because the voltammogram showed reversibility it can be inferred that with further improvement this polymer electrolyte system could be a candidate for li-ion battery application $[16,29,30]$.

While it is promising for solid polymer electrolyte to be developed as conductive separator to ensure safety in lithium-ion battery, it is necessary to improve its quality so that output current and overall capacity could compete the conventional lithium battery using liquid electrolyte.

\section{CONCLUSION}

Solid polymer electrolyte membranes have been synthesized using PVdF-HFP as polymer matrix and LiBOB and LiTFSI as electrolyte salt. Salt concentration was varied at $20 \%, 40 \%$, and $60 \% \mathrm{w} / \mathrm{w}$. FT-IR spectra recognized distinctive peak in the fingerprint region of both salts. Surface and cross-section morphology observed using SEM showed pore formation and homogenous mixture within polymer matrix. Lithium-ion battery half-cells have been assembled using these membranes. Higher salt content resulted in more dense, thicker membrane which gives higher output current. Battery cell with LiTFSI electrolyte presented better output current compared to those with LiBOB electrolyte salt.

\section{ACKNOWLEDGMENT}

This work was supported by Research Centre for Physics, Indonesian Institute of Sciences. We are also grateful for the help of LPPF for material characterization.

\section{REFERENCES}

[1] J. Nunes-Pereira, C. M. Costa, and S. LancerosMéndez, "Polymer composites and blends for battery separators: State of the art, challenges 
and future trends," J. Power Sources, vol. 281, pp. 378-398, 2015.

[2] L. Long, S. Wang, M. Xiao, and Y. Meng, "Polymer electrolytes for lithium polymer batteries," J. Mater. Chem. A, vol. 4, no. 26, pp. 10038-10039, 2016.

[3] W. Li, Y. Xing, X. Xing, Y. Li, G. Yang, and L. Xu, "PVDF-based composite microporous gel polymer electrolytes containing a novelsingle ionic conductor $\mathrm{SiO} 2(\mathrm{Li}+)$," Electrochim. Acta, vol. 112, pp. 183-190, 2013.

[4] V. Aravindan, P. Vickraman, S. Madhavi, A. Sivashanmugam, R. Thirunakaran, and S. Gopukumar, "Improved performance of polyvinylidenefluoride-hexafluoropropylene based nanocomposite polymer membranes containing lithium bis(oxalato)borate by phase inversion for lithium batteries," Solid State Sci., vol. 13, no. 5, pp. 1047-1051, May 2011.

[5] S. S. Zhang, K. Xu, and T. R. Jow, "Study of the charging process of a $\mathrm{LiCoO} 2$-based $\mathrm{Li}$-ion battery," J. Power Sources, vol. 160, no. 2, pp. 1349-1354, Oct. 2006.

[6] Y. Cui, J. Wan, Y. Ye, K. Liu, L. Y. Chou, and Y. Cui, "A Fireproof, Lightweight, Polymer-Polymer Solid-State Electrolyte for Safe Lithium Batteries," Nano Lett., vol. 20, no. 3, pp. 1686-1692, 2020.

[7] P. V. Wright, "Electrical conductivity in ionic complexes of poly(ethylene oxide)," Br. Polym. J., vol. 7, no. 5, pp. 319-327, 1975.

[8] D. E. Fenton, J. M. Parker, and P. V. Wright, "Complexes of alkali metal ions with poly(ethylene oxide)," Polymer (Guildf)., vol. 14, no. 11, p. 589, 1973.

[9] A. Arya and A. L. Sharma, Polymer electrolytes for lithium ion batteries/: a critical study. Ionics, 2017.

[10] K. Xu, U. Lee, S. Zhang, M. Wood, and T. R. Jow, "Chemical Analysis of Graphite/Electrolyte Interface Formed in LiBOB-Based Electrolytes," Electrochem. Solid-State Lett., vol. 6, no. 7, p. A144, 2003.

[11] V. Aravindan and P. Vickraman, "A study on LiBOBbased nanocomposite gel polymer electrolytes (NCGPE) for Lithium-ion batteries," Ionics (Kiel)., vol. 13, no. 4, pp. 277-280, Jul. 2007.

[12] R. Holomb, W. Xu, H. Markusson, P. Johansson, and P. Jacobsson, "Vibrational spectroscopy and $\mathrm{ab}$ initio studies of lithium bis(oxalato)borate (LiBOB) in different solvents," J. Phys. Chem. A, vol. 110, no. 40, pp. 11467-11472, 2006.

[13] J. Jiang, H. Pan, W. Lin, W. Tu, and H. Zhang, "UV-induced semi-interpenetrating polymer electrolyte membrane for elevated-temperature all-solid-state lithium-ion batteries," Mater. Chem. Phys., vol. 236, no. January, p. 121781, 2019.

[14] Z. Du et al., "A mechanically robust, biodegradable and high performance cellulose gel membrane as gel polymer electrolyte of lithium-ion battery," Electrochim. Acta, vol. 299, pp. 19-26, 2019.

[15] R. Prasanth, N. Shubha, H. H. Hng, and M. Srinivasan, "Effect of poly(ethylene oxide) on ionic conductivity and electrochemical properties of poly(vinylidenefluoride) based polymer gel electrolytes prepared by electrospinning for lithium ion batteries," J. Power Sources, vol. 245, pp. 283-291, Jan. 2014.

[16] P. Lv et al., "Robust Succinonitrile-Based Gel Polymer Electrolyte for Lithium-Ion Batteries Withstanding Mechanical Folding and High Temperature," ACS Appl. Mater. Interfaces, vol. 10, no. 30, pp. 25384-25392, 2018.

[17] A. M. Stephan, K. S. Nahm, M. Anbu Kulandainathan, G. Ravi, and J. Wilson, "Poly(vinylidene fluoride-hexafluoropropylene) (PVdF-HFP) based composite electrolytes for lithium batteries," Eur. Polym. J., vol. 42, no. 8, pp. 1728-1734, 2006.

[18] C. Tao et al., "A promising TPU/PEO blend polymer electrolyte for all-solid-state lithium ion batteries," Electrochim. Acta, vol. 257, pp. 31-39, 2017.

[19] A. B. D. Nandiyanto, R. Oktiani, and R. Ragadhita, "How to Read and Interpret FTIR Spectroscope of Organic Material," Indones. J. Sci. Technol., vol. 4, no. 1, pp. 97-118, 2019.

[20] Y. F. Liang et al., "A preeminent gel blending polymer electrolyte of poly(vinylidene fluoridehexafluoropropylene) -poly(propylene carbonate) for solid-state lithium ion batteries," Electrochim. Acta, vol. 296, pp. 1064-1069, 2019.

[21] R. Gonçalves et al., "Solid polymer electrolytes based on lithium bis(trifluoromethanesulfonyl) imide/poly (vinylidene fluoride -co-hexafluoro propylene) for safer rechargeable lithium-ion batteries," Sustain. Mater. Technol., vol. 21, p. e00104, 2019.

[22] S. Ramesh and H. M. Ng, "An investigation on PAN-PVC-LiTFSI based polymer electrolytes system," Solid State Ionics, vol. 192, no. 1, pp. 2-5, 2011.

[23] J. Nunes-Pereira, C. M. Costa, and S. LancerosM??ndez, "Polymer composites and blends for battery separators: State of the art, challenges and future trends," J. Power Sources, vol. 281, pp. 378-398, 2015.

[24] Y. C. Tseng, Y. Wu, C. H. Tsao, H. Teng, S. S. Hou, and J. S. Jan, "Polymer electrolytes based on Poly(VdF-co-HFP)/ionic liquid/carbonate membranes for high-performance lithium-ion batteries," Polymer (Guildf)., vol. 173, pp. 110118, 2019.

[25] S. B. Aziz, O. G. Abdullah, M. A. Rasheed, and H. M. Ahmed, "Effect of high salt concentration (HSC) on structural, morphological, and electrical 
characteristics of chitosan based solid polymer electrolytes," Polymers (Basel)., vol. 9, no. 6, 2017.

[26] L. E. Camacho-Forero, T. W. Smith, and P. B. Balbuena, "Effects of high and low salt concentration in electrolytes at lithium-metal anode surfaces," J. Phys. Chem. C, vol. 121, no. 1, pp. 182-194, 2017.

[27] K. Karuppasamy, D. Kim, Y. H. Kang, K. Prasanna, and H. W. Rhee, "Improved electrochemical, mechanical and transport properties of novel lithium bisnonafluoro-1-butanesulfonimidate (LiBNFSI) based solid polymer electrolytes for rechargeable lithium ion batteries," J. Ind. Eng. Chem., vol. 52, pp. 224-234, 2017.
[28] R. Premila, C. Subbu, S. Rajendran, and K. Selva, "Experimental investigation of nano filler $\mathrm{TiO} 2$ doped composite polymer electrolytes for lithium ion batteries," Appl. Surf. Sci., vol. 449, pp. 426$434,2018$.

[29] N. Elgrishi, K. J. Rountree, B. D. McCarthy, E. S. Rountree, T. T. Eisenhart, and J. L. Dempsey, "A Practical Beginner's Guide to Cyclic Voltammetry," J. Chem. Educ., vol. 95, no. 2, pp. 197-206, 2018.

[30] S. Liang et al., "Gel polymer electrolytes for lithium ion batteries: Fabrication, characterization and performance," Solid State Ionics, vol. 318, no. May, pp. 2-18, 2017. 